\title{
塞栓術を行った破裂脳動脈瘤例における脳血管攣縮の検討
}

\author{
川西 正彦, 新堂 敦, 河北 賢哉 \\ 田宮隆，長尾 省吾
}

\section{Cerebral Vasospasm of Ruptured Cerebral Aneurysms Treated by Coil Embolization}

\author{
Masahiko Kawanishi, M.D., Atsushi Shindou, M.D., Kenya Kawakita, M.D., \\ Takashi TAmiYa, M.D., and Seigo NagaO, M.D. \\ Department of Neurological Surgery, Kagawa University School of Medicine, Kagawa, Japan
}

Summary: We analyzed the incidence of vasospasm (VS) of the cerebral arteries in the patients treated with coil embolization using Guglielmi detachable coils (GDCs) for ruptured cerebral aneurysms, and herein we report the details.

Between March 1997 and March 2005, 52 patients underwent coil embolization within 7 days following rupture of cerebral aneurysms. We excluded 8 patients in whom VS could not be judged due to prolonged disturbance of consciousness resulting from early brain damage consequent to subarachnoid hemorrhage (SAH); early mortality; or other causes, as well as 2 patients in whom VS was already detected at the time of coil embolization. The remaining 42 patients (mean age: 64.4 years) were the subjects of our study. When thick hematomas were revealed on CT scans, spinal drainage was placed until SAH disappeared, while $3 \mathrm{H}$ therapy was actively conducted if the patients showed any manifestations of VS. In addition, when no improvement could be achieved, intra-arterial injection of papaverine hydrochloride was administered or (simultaneous) vascular reconstruction was performed.

Preoperatively, H \& H grade was I in 1 case, II in 16 cases, III in 6 cases, IV in 17 cases, and V in 2 cases. In the Fisher CT group, the grade was 1 in 1 case, 2 in 13 cases, 3 in 25 cases, and 4 in 3 cases. In 11 of the 42 patients (26.2\%), cerebral VS was noticed, and the manifestations such as hemiplegia persisted in 3 (7.1\%).

The incidence of symptomatic cerebral VS following craniotomy is reportedly about $15 \%$ to $30 \%$, but in our present study we found that the incidence was relatively slightly lower following coil embolization. Our results suggest that comparative studies on post-craniotomy cerebral VS should be conducted.

\author{
Key words: \\ - cerebral vasospasm \\ - ruptured cerebral \\ aneurysms \\ - coil embolization
}

Surg Cereb Stroke

(Jpn) 34: 280-283, 2006 


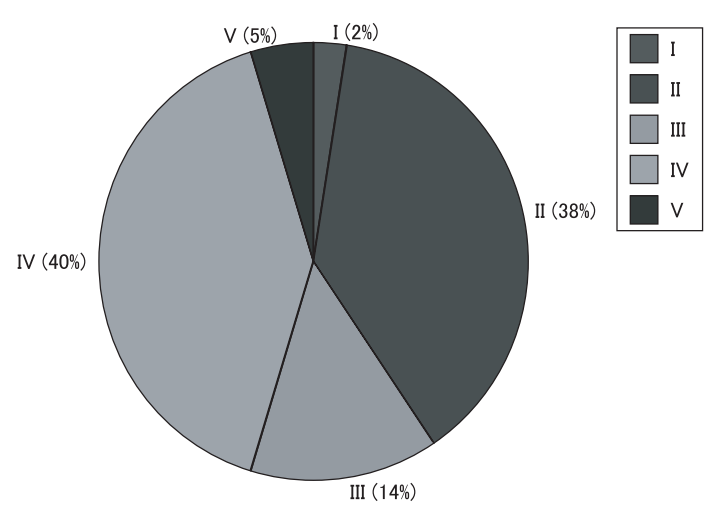

Fig. 1 Hunt \& Hess grade before treatment.

\section{はじめに}

現在でも脳動脈瘤破裂によるくも膜下出血後の脳血管攣 縮は，予後を決定する重要な因子となっている．さらに， 脳血管攣縮は血管撮影上では $70 \%$ に認め，臨床症状を呈 する症例においては 20-30\% で認められると報告されてい る ${ }^{3)}{ }^{4)}$ 10). 近年では, 破裂脳動脈瘤に対する治療法として 瘤内塞栓術を行うことが増加してきており, 塞栓術後の脳 血管攣縮の発生頻度についての報告も多数みうけられる 7) 9) 11)。当施設において塞栓術を行った破裂脳動脈瘤の脳 血管攣縮発生頻度を検討したので報告する。

\section{対象および方法}

1997 年 3 月から 2005 年 3 月までに, 脳動脈瘤破裂後 7 日以内に開頭クリッピング術または瘤内塞栓術が行われた のは 136 例であった. くも膜下出血重症例, 椎骨脳底動脈 系動脈瘤，高齢者，全身合併症の認められる例や本人ある いは家族の強い希望のある症例で，瘤内塞栓術を選択した のは 52 例であった. 52 例において治療開始早期の死亡例 8 例と塞栓術施行時にすでに脳血管攣縮を認めた 2 例を除 いた 42 例を検討の対象とした。年齢は31-89歳 (平均 64.4 歳)で男性 13 例，女性 29 例であった。瘤内塞栓術は可能 な限り全身麻酔下に行い，コイルが挿入できなくなるまで 密に充填し動脈瘤を閉塞した。水頭症や CT 上くも膜下出 血の多かったFisher group 3 以上の症例では塞栓術後持 続腰椎ドレナージを留置した。さらに血腫の排出が不良な 例ではウロキナーゼの䯣腔内投与を行った.脳血管攣縮は, 電解質異常や水頭症などを除外し，急速に進行する意識障 害や神経症状の出現を認めた場合に脳血管撮影を行い診断 した，術前より意識障害を認め，脳血管攣縮を判定できな い症例では発症 7 から 10 日目に脳血管撮影を行い診断し た．塞栓術後は normotension，normovolemiaを基本とし て，脳血管攣縮の徵候が認められれば心肺機能に問題がな

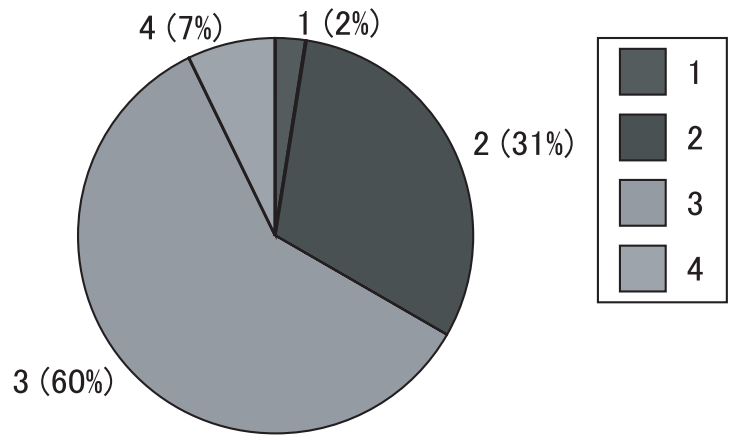

Fig. 2 Fisher group on admission.

ければ，積極的に $3 \mathrm{H}$ 療法を行った。 $3 \mathrm{H}$ 療法を行っても 症状の改善が認められない場合には，攣縮血管が内頸動脈 や中大脳動脈と前大脳動脈の近位部 (M1，A1)の場合には バルーンカテーテルを用いた拡張術を行い，それよりも末 梢側の攣縮の場合には, 塩酸パパベリンの動注を施行した.

\section{結 果}

術前の Hunt \& Hess grade は，I: 1例 (2.4\%)，II: 16 例 (38.1\%)， III: 6 例 (14.3\%)，IV: 17例 (40.5\%)， V: 2 例 (4.8\%)であった Fig. 1)。来院時のCTによる Fisher 分類 は, group 1: 1例 (2.4\%), group 2: 13 例 (31.0\%), group 3: 25 例 (60.0\%), group 4: 3 例 (7.1\%)であった (Fig. 2). 瘤内塞栓術を全例に行い，術後に一過性の血栓性合併症を 3 例 (9\%)に認めた。塞栓程度は，完全閉塞が 23 例 (54.8\%), neck remnant が 15 例 (35.7\%), body filling が 4 例 (10.0\%) であった．塞栓術後に 35 例 (83\%) において持続腰椎ドレ ナージを留置した．塞栓術後の再破裂例は認めていない.

意識状態や神経症状の悪化が認められた例や術前からの 意識障害症例で発症 7 から 10 日目に行った脳血管撮影に おいて脳血管攣縮が認められ，塩酸パパベリンの動注また はバルーン拡張術を行った高度脳血管攣縮例は，42 例中 11 例 (26.2\%) であった (Table 1)．3 例 (7.1\%)に片麻疩など の症状が永続し，2例に無症候性ではあるがCTにて低吸 収域を呈した (Fig. 3)。高度脳血管攣縮を起こした例と起 こさなかった例で年齢, 治療前の重症度, Fisher 分類, 瘤の部位などに有意な差は認められなかったが, Hunt \& Hess gradeの重症例に脳血管攣縮を多くに認め, Fisher 分類では group 3 以上の例が脳血管攣縮 11 例中 10 例であ った(Table 1).

退院時の Glasgow Outcome Scaleは good recovery (GR) が 22 例 (52.3\%), moderately disabled (MD) が 10 例 (23.8\%), severely disabled (SD) が6例 (14.3\%), vegetative survival が2例 (4.8\%), dead (D) が2 例 (4.8\%) であっ 
Table 1 Summary of patients affected cerebral vasospasm

\begin{tabular}{ccccccc}
\hline Case & Location of $\mathrm{An}$ & $\mathrm{H} \& \mathrm{H}$ & Fisher & Spinal draninage & Low density on CT & DIND \\
\hline 1 & VA & V & 3 & + & - & - \\
2 & ICPC & IV & 3 & + & - & - \\
3 & VA & IV & 3 & + & - & - \\
4 & BA & IV & 3 & + & - & - \\
5 & ICPC & II & 3 & + & - & - \\
6 & AC & IV & 4 & + & - & - \\
7 & MC & II & 2 & - & + & - \\
8 & ICPC & IV & 4 & - & + & - \\
9 & ICPC & II & 3 & + & + & + \\
10 & ICPC & III & 3 & + & + & + \\
11 & ICPC & IV & 3 & + & + & + \\
\hline
\end{tabular}

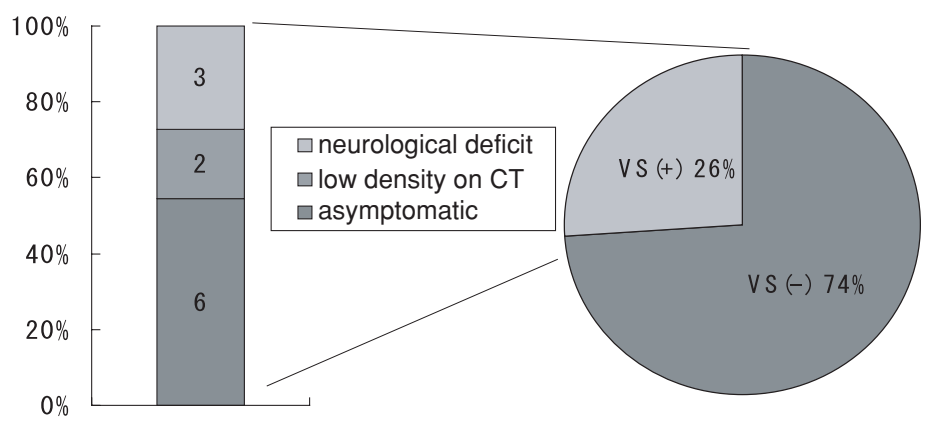

Fig. 3 Outcome of patients with cerebral vasospasm.

た，GR，MDを含めた予後良好例は $75 \%$ であった.

\section{考察}

破裂脳動脈瘤の治療法として, 瘤内塞栓術は開頭術と比 べ低侵襲でもあり今後症例数も増加してくることが予想さ れる．しかし，動脈瘤破裂によるくも膜下出血において脳 血管攣縮は予後を決定づける大きな要因であり, 塞栓術後 の発生頻度を知ることは重要であると考えられる．開頭ク リッピング術においては, 脳血管攣縮が血管撮影上では 70-90\% の症例で認められ, 症候性のものは 25-37\%, 永 続的な神経脱落症状を呈するものが 7-17\% に認められる とされている ${ }^{4)}$. 以前より開頭手術の際には，直視下に血 腫を除去することで脳血管攣縮を軽減することができるこ とが報告され ${ }^{8)}$, 最近では Kawamoto ら ${ }^{4)}$ は術中に可及的 に血腫を除去したのち, さらに残存血腫の排出のための工 夫を行い症候性脳血管攣縮を $15.2 \%$, 永続的な神経脱落症 状を $2.7 \%$ まで減弱できたと報告している。また, Gruber $ら^{1)}$ は, くも膜下出血治療後の脳梗塞発生頻度は $26 \%$ で あったと報告し, 開頭術よりも塞栓術例のほうが脳梗塞発 生率が高かったことを報告している.

Murayama $ら^{7)}$ は動脈瘤塞栓術後の脳血管攣縮の発生頻
度について, 症候性脳血管攣縮を $23 \%$ に認め, 神経症状 を永続したものが $2.8 \%$ であったと報告している．今回の われわれの検討では, 塞栓術後の無症候性も含めて脳血管 攣縮は $26.2 \% に$ 認め, 神経脱落症状を永続したものが $7.1 \%$ であった。この頻度は通常の開頭術後の脳血管攣縮 発生頻度と同等かやや低值と考えられる. Murayama ら の報告に比べやや永続的神経脱落症状を残した例が多い が，彼らの報告では術前の重症度が grade I-IIIに限られ ており，われわれの症例には grade IV，Vの症例が $45 \%$ に認められ，発生頻度が高くなったことが予想される.

開頭手術の場合には，発症早期にくも膜下腔の血腫を可 及的に除去することで攣縮を予防できるとされている ${ }^{6)}$ が.一方では, Yoshimotoら ${ }^{12)} は$, 開頭術後の術側と反 対側の脳血流を比較し有意差は認めず，脳血管攣縮の発生 には手術による脳の圧排などの影響があるものと考察して いる，開頭術と違い，塞栓術の場合，血腫を直接的に除去 することはできない. しかし，〈も膜を切開することがな く正常の脳脊髄液循環が保たれるため, くも膜下腔の血腫 のクリアランスがよいことが予想される，さらには，脳実 質や脳血管への機械的刺激が少なくそれらへの直接的な影 響がないことによって, 脳血管攣縮の発生頻度が開頭術と 
同等かもしくはやや低い傾向を示すのではないかと考えら れる．今回の報告では，脳血管攣縮の発生とくも膜下血腫 のクリアランスについての検討は行えていないが，血腫早 期排除のための持続的脊椎ドレナージの有効性も報告され ており ${ }^{5)}$ ，塞栓術とドレナージの併用にて今後さらに脳血 管攣縮の発生を低下させうると考えられる。

\section{結 論}

開頭術後の症候性 VS の発生頻度は約 15-30\% といわれ ている.われわれの検討では瘤内塞栓術施行例ではくも膜 下出血重症例が多いにもかかわらず，開頭術後と同程度か やや低い傾向が認められた．今後腰椎ドレナージやウロキ ナーゼの髄腔内投与との併用でさらに減少させうると考え られる。

\section{文献}

1) Gruber A, Ungersbock K, Reinprecht A, et al: Evaluation of cerebral vasospasm after early surgical and endovascular treatment of ruptured intracranial aneurysms. Neurosurgery 42: 258-267; discussion 267-258, 1998

2) Hohlrieder M, Spiegel M, Hinterhoelzl J, et al: Cerebral vasospasm and ischaemic infarction in clipped and coiled intracranial aneurysm patients. Eur J Neurol 9: 389-399, 2002

3) Kassell NF, Sasaki T, Colohan AR, et al: Cerebral vasospasm following aneurysmal subarachnoid hemorrhage. Stroke 16: 562-572, 1985

4) Kawamoto S, Tsutsumi K, Yoshikawa G, et al: Effec- tiveness of the head-shaking method combined with cisternal irrigation with urokinase in preventing cerebral vasospasm after subarachnoid hemorrhage. J Neurosurg 100: 236-243, 2004

5) Klimo P Jr, Kestle JR, MacDonald JD, et al: Marked reduction of cerebral vasospasm with lumbar drainage of cerebrospinal fluid after subarachnoid hemorrhage. $J$ Neurosurg 100: 215-224, 2004

6) Macdonald RL, Wallace MC, Coyne TJ: The effect of surgery on the severity of vasospasm. J Neurosurg 80: 433-439, 1994

7) Murayama Y, Malisch T, Guglielmi G, et al: Incidence of cerebral vasospasm after endovascular treatment of acutely ruptured aneurysms: report on 69 cases. J Neurosurg 87: 830-835, 1997

8) Ohta H, Ito Z, Yasui N, et al: Extensive evacuation of subarachnoid clot for prevention of vasospasm-effective or not? Acta Neurochir (Wien) 63: 111-116, 1982

9) Rabinstein AA, Pichelmann MA, Friedman JA, et al: Symptomatic vasospasm and outcomes following aneurysmal subarachnoid hemorrhage: a comparison between surgical repair and endovascular coil occlusion. J Neurosurg 98: 319-325, 2003

10) Weir B, Macdonald RL, Stoodley M: Etiology of cerebral vasospasm. Acta Neurochir Suppl 72: 27-46, 1999

11) Yalamanchili $\mathrm{K}$, Rosenwasser $\mathrm{RH}$, Thomas JE, et al: Frequency of cerebral vasospasm in patients treated with endovascular occlusion of intracranial aneurysms. AJNR 19: $553-558,1998$

12) Yoshimoto $Y$, Wakai S, Satoh A, et al: A prospective study on the effects of early surgery on vasospasm after subarachnoid hemorrhage. Surg Neurol 51: 392-397, discussion 397-398, 1999 